\title{
Growth and survival of bay anchovy Anchoa mitchilli larvae in mesocosm enclosures*
}

\author{
James H. Cowan Jr, Edward D. Houde \\ The University of Maryland System, Center for Environmental and Estuarine Studies, Chesapeake Biological Laboratory \\ Solomons, Maryland 20688-0038, USA
}

\begin{abstract}
Factors that affect survival and growth of bay anchovy Anchoa mitchilli larvae in the Chesapeake Bay, USA, were studied in situ in $3.2 \mathrm{~m}^{3}$ mesocosm enclosures. Experiments tested the effects of variable prey level and anchovy egg and larvae densities on growth and survival of larvae to at least $16 \mathrm{~d}$ post-hatching. Eggs were stocked at $100 \mathrm{~m}^{-3}$ with microzooplankton $(<150 \mu \mathrm{m})$ prey added at nominal levels of $50,500,1500$, or $50001^{-1}$. In a second series of experiments, eggs were stocked at 10 , 100 , or $\geq 1000 \mathrm{~m}^{-3}$ and prey level was maintained near $500 \mathrm{l}^{-1}$. Larvae growth was rapid $(0.39$ to $0.63 \mathrm{~mm} \mathrm{~d}^{-1}$ ), even at the lowest prey levels and highest initial egg stocking densities. Growth rates tended to decrease as egg density increased. Instantaneous mortality rates were high ( 0.08 to $\left.0.23 \mathrm{~d}^{-1}\right)$ but lower than those reported for bay anchovy larvae from estuaries with gelatinous zooplankton and fish predators present. Highest mortality unexpectedly occurred in mesocosms with the highest prey level and lowest mortality occurred in enclosures with the highest initial egg stocking densities. Relative production decreased as prey level increased but $G_{W}: Z$ ratios were above unity for all except the highest prey level experiment. In the stocking density experiments, highest production occurred in enclosures with the lowest initial egg densities. Some unexpected results may have been induced by effects of the mesocosm enclosures.
\end{abstract}

\section{INTRODUCTION}

High annual variability in recruitment success is characteristic of most populations of marine fishes. Although it is widely acknowledged that year-class strength is probably determined during early life and the significance of mortality during early life to recruitment of adult stocks is well documented (Cushing 1975, Hunter 1981, Lasker 1981), causes of variability and the mechanisms that potentially regulate recruitment remain poorly understood. Small changes in mortality and growth rates during early life, attributable to variable predation, starvation, and oceanographic conditions, can lead to 10 -fold or greater differences in year-class abundance (Houde 1987). However, in situ estimation of vital rates of fish early life stages is difficult due to the sampling effort necessary to account for both spatial and temporal fluctuations in population distribution and abundance (Taggart \& Leggett 1987).

Recently, large volume enclosures (mesocosms) have been successfully used to study factors believed to

\footnotetext{
- Contribution No. 2163 of the University of Maryland Center
} for Environmental and Estuarine Studies regulate recruitment in marine fish populations (Laurence et al. 1979, Øiestad 1982, 1988, Houde 1985, de Lafontaine \& Leggett 1987a, b, 1988, Gamble \& Fuiman 1987, Fuiman \& Gamble 1988). Experiments in situ have been conducted in enclosures with volumes that were large enough $\left(>3 \mathrm{~m}^{3}\right)$ to allow fish eggs and larvae, their predators and prey to be stocked at abundance levels near those that occur in the sea. Consequently, results have provided new knowledge about the dependency of fish early life stages upon environmental factors.

We report here our use of large volume $\left(3.2 \mathrm{~m}^{3}\right)$ enclosures to study growth and survival of bay anchovy Anchoa mitchilli larvae in a tidal subestuary of the Chesapeake Bay (Patuxent River), USA. The bay anchovy is a small ( $<110 \mathrm{~mm}$ total length) planktivorous fish that is abundant in the coastal western north Atlantic and is the most abundant fish in the Chesapeake Bay (Hildebrand \& Schroeder 1928). It is abundant in all life stages and is an important trophic link between plankton and piscivorous fishes (Baird \& Ulanowicz 1990).

Growth and survival of bay anchovy larvae were examined in relation to microzooplankton prey level 
and initial stocking density of anchovy eggs/larvae. Most prey levels and stocking densities were selected from the range likely to be experienced by bay anchovy in the Chesapeake Bay. However, higher prey level $\left(5000 \mathrm{l}^{-1}\right)$ and stocking density $\left(\geq 1000\right.$ eggs $\left.\mathrm{m}^{-3}\right)$ experiments also were included to determine if they would dramatically alter growth or survival rates.

\section{METHODS AND MATERIALS}

Deployment and retrieval of enclosures. The enclosures (mesocosms) were based on the design of de Lafontaine \& Leggett (1987a) and were $1 \mathrm{~m}$ diameter cylinders of $5 \mathrm{~m}$ length with a conical bottom section, giving an internal volume of $32001\left(3.2 \mathrm{~m}^{3}\right)$. The body of the enclosure was divided into four $1 \mathrm{~m}$ sections constructed from white, 2.2-oz Dacron sail cloth with an average mesh aperture of $\sim 25 \mu \mathrm{m}$ (range 15 to $34 \mu \mathrm{m}$ ). The conical end section was constructed of $53 \mu \mathrm{m}$ Nitex mesh. The sections were joined by $10 \mathrm{~cm}$ bands of untreated canvas on the external side of the enclosures. Solid, $6 \mathrm{~mm}$ stainless steel hoops were lashed to the canvas bands to support the enclosure walls and facilitate retrieval. A 11 , PVC cod-end was secured to the bottom of the enclosure to recover the experimental organisms at the end of each deployment.

The enclosures were moored in $10 \mathrm{~m}$ depth near the mouth of the Patuxent River, a subestuary of the Maryland portion of the Bay $\left(38^{\circ} 21^{\prime} \mathrm{N}, 76^{\circ} 31^{\prime} \mathrm{W}\right)$. They were deployed by allowing them to fill by diffusion of water ( $\sim 5 \mathrm{~min})$ through the sail cloth and Nitex walls after securing them within circular openings in $2 \times 4 \mathrm{~m}$ wooden rafts, each designed to support 2 filled enclosures. Three of the wooden rafts were joined and anchored on a 2-point mooring, creating a 6-enclosure platform on which several people could stand and work. The enclosures were retrieved with a handoperated winch on a portable wooden A-frame. The retrieval process required from 0.5 to $1.5 \mathrm{~h}$, depending on the degree of fouling on the enclosure.

Experimental design and data analysis. Growth rate, its variability, and survival rate of eggs and larvae of bay anchovy in relation to microzooplankton prey levels and egg stocking density were examined in randomly-assigned, duplicate experimental treatments from 25 June to 26 September 1988 (Table 1). Anchovy eggs were obtained from a spawning population maintained at the Chesapeake Biological Laboratory. Fertilized eggs were collected in the morning, counted and delivered to the enclosure site. Prey for larvae was netcollected zooplankton captured near the raft and concentrated in a $100 \mathrm{l}$ container after filtering through Nitex sieves to remove organisms $>150 \mu \mathrm{m}$. Numbers of prey $1^{-1}$ [primarily Acartia sp. nauplii $(70 \%)$, the rotifers Synchaeta sp. and Brachionus sp. (10 to $15 \%$ ) and the tintinnids Tintinnopsis sp. and Eutintinnus sp. (5 to $10 \%$ )] were enumerated and the volumes of concentrate required for experimental prey levels were added to enclosures. The 4 designated prey levels were: (1) ambient ( $\sim 500$ microzooplankton $\left.1^{-1}\right)$; (2) $0.1 \times$ depleted $\left(\sim 50 \mathrm{l}^{-1}\right)$; (3) $2.5 \times$ enhanced $(\sim 1500$ $\left.\mathrm{l}^{-1}\right)$; and (4) $10 \times$ enhanced $\left(\sim 500 \mathrm{l}^{-1}\right)$. Anchovy eggs were stocked in the enclosures one day before the microzooplankton prey was added. Anchovy eggs hatch in $<24 \mathrm{~h}$ at 25 to $28^{\circ} \mathrm{C}$. Experiments were run until larvae were 16 to $22 \mathrm{~d}$ post-hatch (dph) (Table 1).

For the stocking density experiments, microzooplankton prey level was maintained near ambient ( 500 prey $\left.1^{-1}\right)$ and the number of anchovy eggs added to enclosures was varied. Eggs were stocked at: (1)

Table 1. Date of deployment and stocking densities of microzooplankton prey and anchovy eggs in the 1988 enclosure experiments. Also given is duration of deployment (days post-hatch; dph)

\begin{tabular}{|c|c|c|c|c|c|c|}
\hline \multirow{2}{*}{$\begin{array}{c}\text { Date } \\
\text { deployed } \\
(1988)\end{array}$} & \multicolumn{4}{|c|}{ Stocking density } & \multirow{2}{*}{$\begin{array}{c}\text { Duration } \\
\text { (dph) }\end{array}$} & \multirow{2}{*}{ Replicate } \\
\hline & $\begin{array}{c}\text { Nominal } \\
\text { anchovy eggs } \\
\left(\mathrm{m}^{-3}\right)\end{array}$ & $\begin{array}{c}\text { Actual } \\
\text { anchovy eggs } \\
\left(\mathrm{m}^{-3}\right)\end{array}$ & $\begin{array}{l}\text { Nominal } \\
\text { prey conc. } \\
\left(1^{-1}\right)\end{array}$ & $\begin{array}{l}\text { Actual mean } \\
\text { prey conc. } \\
\left(1^{-1}\right)\end{array}$ & & \\
\hline $2 \mathrm{Jul}$ & 10 & 10 & 500 & 578 & 19 & A \\
\hline 3 Jul & 10 & 10 & 500 & 531 & 19 & B \\
\hline $3 \mathrm{Jul}$ & 100 & 55 & 50 & 73 & 16 & A \\
\hline $7 \mathrm{Jul}$ & 100 & 69 & 50 & 65 & 16 & B \\
\hline $15 \mathrm{Jul}$ & $\geq 1000$ & $\sim 1300$ & 500 & 510 & 16 & A \\
\hline $15 \mathrm{Jul}$ & $\geq 1000$ & $\sim 1300$ & 500 & 500 & 16 & B \\
\hline $23 \mathrm{Jul}$ & 100 & 100 & 500 & 503 & 17 & A \\
\hline $24 \mathrm{Jul}$ & 100 & 100 & 500 & 503 & 16 & B \\
\hline $25 \mathrm{Jul}$ & 100 & 100 & 5000 & 4776 & 17 & A \\
\hline 26 Jul & 100 & 100 & 5000 & 4022 & 16 & B \\
\hline $18 \mathrm{Aug}$ & 100 & 100 & 1500 & 1200 & 22 & A \\
\hline $18 \mathrm{Aug}$ & 100 & 100 & 1500 & 1310 & 22 & B \\
\hline
\end{tabular}


$10 \mathrm{~m}^{-3}$; (2) $100 \mathrm{~m}^{-3}$; and (3) $\geq 1000 \mathrm{~m}^{-3}$ (actual number $\sim 1300 \mathrm{~m}^{-3}$; determined volumetrically). Experiments were run until larvae were 16 to $19 \mathrm{dph}$ (Table 1).

Temperature and salinity were measured at $48 \mathrm{~h}$ intervals inside each enclosure and outside near the raft at surface, 1, 2, 3, 4 and $5 \mathrm{~m}$ depths using a YSI Salinometer Model 55. Dissolved oxygen and light intensity profiles inside and outside the enclosures at $1 \mathrm{~m}$ depth intervals were determined less frequently using a dissolved oxygen meter (YSI Model 58) and photometer (Li-Cor Model Li-188B), respectively. Profiles were taken during daylight hours between 06:00 and $17: 00 \mathrm{~h}$ and at tide stages from full-flood to fullebb.

Data on microzooplankton prey concentration and larvae growth in the enclosures were obtained by 2 methods: (1) submersible plankton pump having a mean flow rate of $501 \mathrm{~min}^{-1}$; and, (2) $40 \mathrm{~cm}$ diameter plankton net with $280 \mu \mathrm{m}$ mesh. Depth-integrated pump samples (10 l) were taken by slowly retrieving the pump from near the enclosure's cod-end to the surface and then concentrating the sample on a $35 \mu \mathrm{m}$ mesh sieve. Plankton net samples consisted of single vertical lifts from cod-end to surface. Pump and net samples were taken at $48 \mathrm{~h}$ intervals. Pump, net, and cod-end samples of concentrated zooplankton and surviving anchovy larvae at the end of each experiment were preserved in $4 \%$ buffered formalin, then transferred to $70 \%$ ethanol within $48 \mathrm{~h}$.

Prey levels were adjusted by (1) removing some adult copepods every $48 \mathrm{~h}$ to reduce their egg production and potential cannibalism on nauplii $(20 \%$ of water volume in the mesocosms was filtered by each lift of the $40 \mathrm{~cm}$ plankton net); and (2) adding microzooplankton during the experiment. Removal of adults was the primary control in the low prey level treatments $(50$ prey $1^{-1}$ ) while microzooplankton occasionally was added to high prey $\left(1500,5000\right.$ prey $\left.1^{-1}\right)$ and high stocking density $\left(\geq 1000\right.$ eggs $\left.1^{-1}\right)$ experiments to maintain prey near nominal levels (Table 1).

Larvae standard lengths (SL) and several body dimensions, including body depth at anus and pectoral fin buds, eye diameter and head length, were measured to the nearest $0.1 \mathrm{~mm}$ for growth determination and morphologic comparisons of larvae condition. The ratios of pectoral body depth and anal body depth to standard length were used as a standard morphologic comparison of larvae condition between treatments (Theilacker 1978). Instantaneous growth-in-length $\left(G_{L}\right)$ and mortality rates were calculated from exponential models:

$$
\mathrm{L}_{\mathrm{t}}=\mathrm{L}_{\mathrm{o}} \mathrm{e}^{\mathrm{G}_{\mathrm{L}} \mathrm{t}}
$$

where $\mathrm{G}_{\mathrm{L}}=$ instantaneous growth rate $\left(\mathrm{d}^{-1}\right) ; \mathrm{L}_{\mathrm{t}}=$ standard length $(\mathrm{mm})$ at time $\mathrm{t}$ in days; $\mathrm{L}_{\mathrm{o}}=$ standard length $(\mathrm{mm})$ at time $0 ; \mathrm{t}=$ time $(\mathrm{dph})$, and

$$
\mathrm{N}_{\mathrm{t}}=\mathrm{N}_{\mathrm{o}} \mathrm{e}^{-\mathrm{Zt}}
$$

where $\mathrm{Z}=$ instantaneous mortality rate $\left(\mathrm{d}^{-1}\right) ; \mathrm{N}_{\mathrm{t}}=$ number of larvae alive at time $t$ in days; $N_{o}=$ number of eggs stocked in an enclosure.

To account for larvae collected by pump and net sampling in the enclosures, expected numbers of survivors had there been no sampling were estimated by:

$$
\begin{gathered}
\mathrm{Z}=\mathrm{F}+\mathrm{M} \\
\mathrm{N}_{\mathrm{t}}=\mathrm{N}_{\mathrm{o}} \mathrm{e}^{-(\mathrm{F}+\mathrm{M}) \mathrm{t}}
\end{gathered}
$$

where $\mathrm{F}=$ sampling instantaneous mortality rate $\left(\mathrm{d}^{-1}\right)$; $\mathrm{M}=$ expected instantaneous mortality rate in the absence of sampling $\left(\mathrm{d}^{-1}\right)$.

Knowing $\mathrm{N}_{\mathrm{o}}, \mathrm{N}_{\mathrm{t}}, \mathrm{Z}$ and $\mathrm{F}$, the equation was solved for $\mathrm{M}$ and the number of expected survivors was calculated by $\mathrm{N}_{\mathrm{t}}=\mathrm{N}_{\mathrm{o}} \mathrm{e}^{-\mathrm{Mt}}$.

Estimated instantaneous growth-in-weight coefficients $\left(\hat{G}_{\mathrm{W}}\right)$ were calculated based on a length-weight relationship for bay anchovy larvae (Houde unpubl.):

$$
\mathrm{W}_{\mathrm{t}}=0.1550 \mathrm{~L}_{\mathrm{t}}^{3.53}
$$

where $\mathrm{W}_{\mathrm{t}}=$ dry weight of larvae in $\mu \mathrm{g}$ at age $\mathrm{t}$ in days.

$$
\begin{aligned}
& \mathrm{W}_{\mathrm{t}}=0.1550\left[\mathrm{~L}_{\mathrm{o}} \mathrm{e}^{\mathrm{G}_{\mathrm{t} t}}\right]^{3.53} \\
& \hat{\mathrm{G}}_{\mathrm{W}}=\frac{\log _{\mathrm{e}} \mathrm{W}_{\mathrm{t}}-\log _{\mathrm{e}} \mathrm{W}_{\mathrm{o}}}{\mathrm{t}}
\end{aligned}
$$

where $\mathrm{L}_{\mathrm{o}}=$ length-at-hatch of bay anchovy larvae $(\sim 2.20 \mathrm{~mm} \mathrm{SL}) ; \mathrm{W}_{\mathrm{o}}=$ dry weight $(\mu \mathrm{g})$ of bay anchovy eggs $(\sim 25 \mu \mathrm{g})$.

Production estimates were based on the relationship described by Ricker (1975):

$$
\hat{\mathrm{P}}=\hat{\mathrm{G}}_{\mathrm{W}} \overline{\mathrm{B}}
$$

where $\hat{\mathrm{P}}=$ estimated production in $\mu \mathrm{g}$ dry weight $\mathrm{d}^{-1}$; $\overline{\mathrm{B}}=$ the mean biomass present during the unit time interval $\Delta \mathrm{t}$ in days

$$
\begin{aligned}
\bar{B}=\frac{B_{0}\left[e^{\left(\hat{G}_{w}-Z\right) t}-1\right]}{\left(\hat{G}_{W}-Z\right) t} & (G>Z) \\
\bar{B}=\frac{B_{0}\left[1-e^{-\left(Z-G_{w}\right) t}\right]}{\left(Z-\hat{G}_{W}\right) t} & (Z>G)
\end{aligned}
$$

where $B_{0}=$ biomass of eggs $\left(\mu \mathrm{g} \mathrm{m}^{-3}\right)$ stocked in each enclosure.

Relative production, standardized to number of stocked anchovy eggs, is:

$$
\hat{\mathrm{P}}_{\mathrm{s}}=\hat{\mathrm{P}} / \mathrm{N}
$$

where $\mathrm{N}=$ number of anchovy eggs $\mathrm{m}^{-3}$ stocked in each enclosure.

Standardization allowed comparison among experiments with different stocking densities of eggs. 


\section{RESULTS}

\section{Water column properties}

Weekly mean salinity and temperature at the surface ( 0 to $1 \mathrm{~m}$ ), mid-depth ( 2 to $3 \mathrm{~m}$ ) and in deep (4 to $5 \mathrm{~m}$ ) waters inside and outside the enclosures closely resembled each other during the $13 \mathrm{wk}$ that mesocosms were deployed (Fig. 1A, B). Daily profiles taken at $1 \mathrm{~m}$ depth intervals were more variable but indicated that waters inside the enclosures responded quickly to diel and tidal fluctuations in salinity and temperature. Daily values inside the enclosures were within $\pm 1 \%$ and $\pm 1^{\circ} \mathrm{C}$ for salinity and temperature, respectively, of values in ambient waters on all but one of the 112 profiles taken. The single exception occurred on 15 August 1988 when salinity at mid-depth and in deep waters inside one enclosure was $5 \%$ higher than in ambient waters. The temperature profile on that day was similar inside and outside the enclosure.

Internal and external profiles of dissolved oxygen (DO), taken when ambient water temperatures were 27 to $29^{\circ} \mathrm{C}$, indicated that average concentration of DO in the enclosures was higher than in ambient waters (Fig. 2A). Mean DO in the enclosures was $7.0 \mathrm{ppm}$ at the surface. It gradually declined to $5.5 \mathrm{ppm}$ at $4 \mathrm{~m}$ depth and then declined more rapidly to $3.1 \mathrm{ppm}$ at $5 \mathrm{~m}$ depth, presumably due to anoxic conditions caused by detritus that had accumulated in the cod-end. Mean DO concentration outside the enclosures was $4.9 \mathrm{ppm}$ at the surface; it then slowly decreased to $4.3 \mathrm{ppm}$ at $5 \mathrm{~m}$ depth.

Light intensity inside the enclosure decreased more rapidly with depth than in ambient waters outside (Fig. 2B). Although mean values were similar at the surface

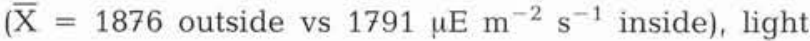
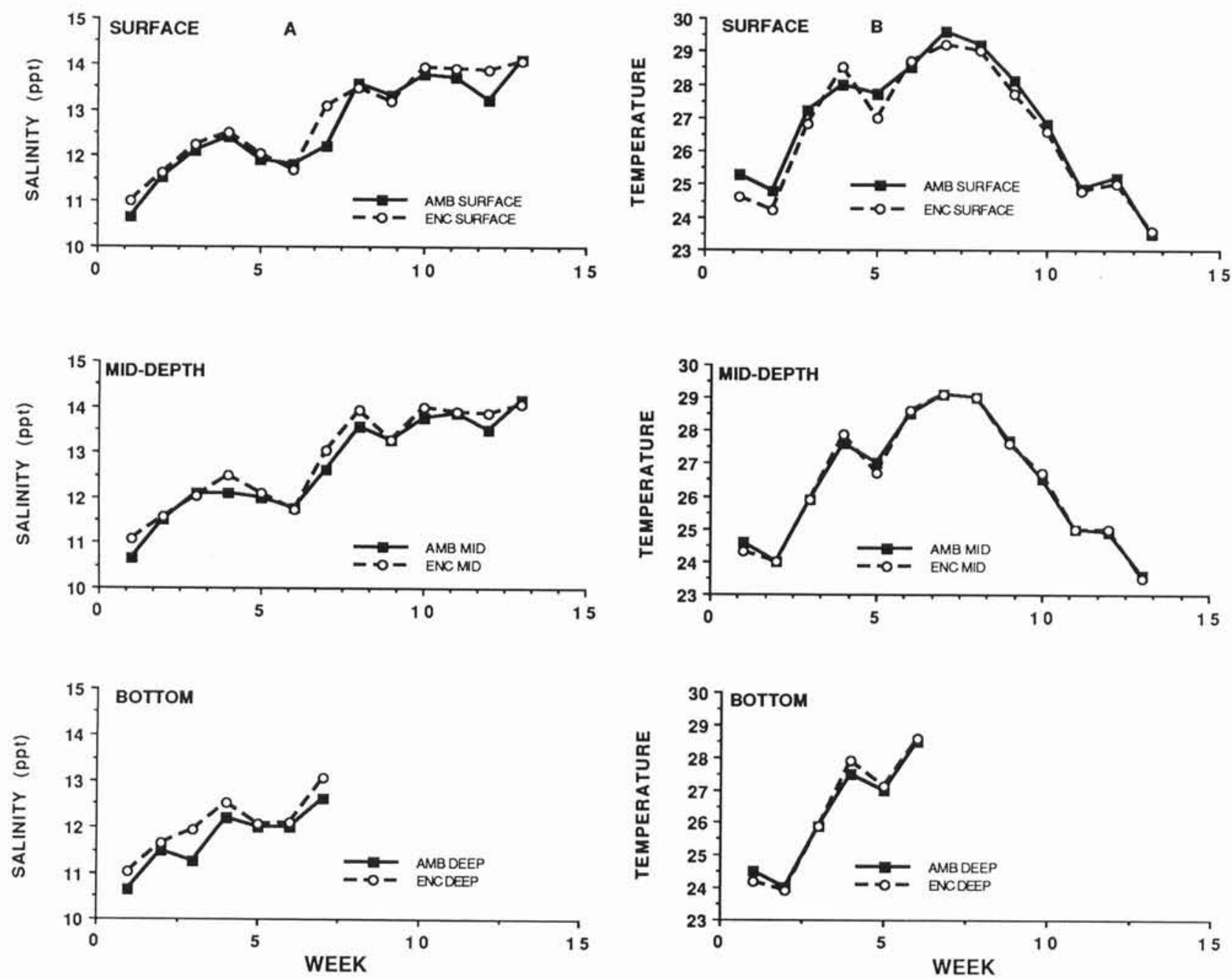

Fig. 1. Weekly mean salinity (A) and temperature (B) of waters inside and outside enclosures at the surface (0 to $1 \mathrm{~m})$, mid-depth (2 to $3 \mathrm{~m}$ ) and bottom $(4$ to $5 \mathrm{~m})$. Bottom values of salinity and temperature were not recorded in Weeks 8 to 13 due to equipment failure 


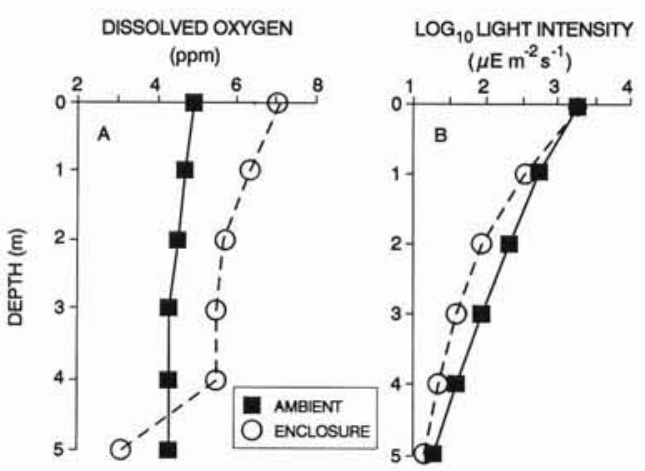

Fig. 2. Internal and external depth profiles of mean dissolved oxygen (A) and light intensity (B) during enclosure experiments

intensity at $1 \mathrm{~m}$ depth inside the enclosures was only $60 \%$ of that outside; below $1 \mathrm{~m}$, mean values inside the enclosures were ca $50 \%$ of mean values outside.

\section{Anchovy larvae growth and survival}

Prey level experiments (Expt I)

Larvae in the enclosures grew rapidly at all experimental prey levels (Table 2). The highest observed mean growth rate $\left(0.63 \mathrm{~mm} \mathrm{~d}^{-1}\right)$ occurred at the lowest prey level $\left(\sim 50\right.$ prey $\left.1^{-1}\right)$. Mean growth rate ranged from 0.39 to $0.63 \mathrm{~mm} \mathrm{~d}^{-1}$, giving instantaneous growthin-length coefficients $\left(\mathrm{G}_{\mathrm{L}}\right)$ ranging from 0.09 to 0.11 $\mathrm{d}^{-1}$, during the prey level experiments (Table 2). These growth rates ( $\mathrm{mm} \mathrm{d}^{-1}$ and $\mathrm{G}_{\mathrm{L}}$ ) did not differ significantly in relation to prey level or mean surface temperature (2-way ANOVA, $\mathrm{p}>0.15$ ), which ranged from 25.7 to $28.0^{\circ} \mathrm{C}$ during the experiments. Differences in larvae growth rate $\left(\mathrm{mm} \mathrm{d}^{-1}\right.$ and $\left.\mathrm{G}_{\mathrm{L}}\right)$ between duplicate treatments also were not significant (ANOVA, $\mathrm{p}>0.65$ ).

The variability in instantaneous growth rate $\left(\mathrm{G}_{\mathrm{L}}\right)$ was high for individual survivors in prey level experiments. Individual rates range from 0.07 to $0.13 \mathrm{~d}^{-1}$ (Table 3 ). Coefficients of variation (CV) about mean $\mathrm{G}_{\mathrm{L}}$ of surviving larvae ranged from $0.3 \%$ at 5000 prey $\mathrm{l}^{-1}$ to $9.7 \%$ at 50 prey $1^{-1}$ (Table 3). Although there was no systematic change in the $\mathrm{CV}$, the range of $\mathrm{G}_{\mathrm{L}}$ of survivors within a prey level treatment decreased as prey level increased (regression analysis, range of $G_{L}$ on $\log _{10}$ prey level, $\mathrm{p}<0.005$ ). However, standard morphologic comparisons of larvae condition did not vary significantly between prey level treatments (ANCOVA, $\mathrm{p}>0.05$ ).

Instantaneous daily mortality rates (Z) of bay anchovy eggs and larvae in the enclosures differed among prey levels (Table 2). Unexpectedly, mortality rate was significantly higher at the highest prey level
(ANOVA, p <0.02). No larvae survived to $16 \mathrm{dph}$ in one of the duplicate $10 \times$ enhanced prey level treatments while only 2 survived in the other. At the $2.5 \times$ enhanced prey level, mortality averaged $18.8 \% \mathrm{~d}^{-1}$ while at the 2 lower prey levels it averaged only $12.7 \%$ $\mathrm{d}^{-1}$.

The ratio of estimated growth-in-weight $\left(\hat{G}_{W}\right)$ to instantaneous mortality coefficients ( $\hat{G}_{W}: Z_{;}$Table 3$)$ decreased as prey level increased (regression analysis, $\hat{\mathrm{G}}_{\mathrm{W}}: \mathrm{Z}$ on $\log _{10}$ prey level, $\mathrm{p}<0.001$ ) but were greater than unity for all but the highest prey level treatment. The estimate of standardized production $\left(\hat{\mathrm{P}}_{\mathrm{s}}\right)$ decreased as prey level increased (regression analysis, $\hat{\mathrm{P}}_{\mathrm{s}}$ on $\log _{10}$ prey level, $\mathrm{p}<0.003$ ).

\section{Stocking density experiments (Expt II)}

Mean instantaneous growth-in-length coefficients $\left(\mathrm{G}_{\mathrm{L}}\right)$ were $0.10,0.095$, and 0.09 at the 3 stocking densities of 10,100 and $\sim 1300 \mathrm{~m}^{-3}$, respectively (Table 2). The coefficients tended to decrease as stocking density increased but differences in mean $G_{L}$ were not significant among stocking densities or in relation to 2 wk mean temperature $\left(26.0\right.$ to $\left.28.0^{\circ} \mathrm{C}\right)$ during deployment (2-way ANOVA, $\mathrm{p}>0.65$ ). Differences in larvae growth rates $\left(\mathrm{mm} \mathrm{d}^{-1}\right.$ and $\mathrm{G}_{\mathrm{L}}$ ) between duplicate treatments also were not significant (ANOVA, $\mathrm{p}>0.75$ ).

The regression of growth-in-length rates $\left(\mathrm{mm} \mathrm{d}^{-1}\right)$ of bay anchovy larvae on $\log _{10}$ stocking density did indicate that growth rate declined significantly (t-test, $\mathrm{p}<0.02$ ) as initial stocking density increased (Table 2). The highest mean growth rate $\left(0.59 \mathrm{~mm} \mathrm{~d}^{-1}\right)$, based on only 4 survivors, occurred when eggs were stocked at $10 \mathrm{~m}^{-3}$. Mean growth rate decreased to $0.48 \mathrm{~mm} \mathrm{~d}^{-1}$ at 100 eggs $\mathrm{m}^{-3}$ and $0.41 \mathrm{~mm} \mathrm{~d}^{-1}$ at $\sim 1300$ eggs $\mathrm{m}^{-3}$ stocking densities.

A linear regression relationship of growth rate on $\log _{10}$ stocking density was used to approximate potential maximum growth rate of bay anchovy larvae in the enclosures. The equation, growth rate $\left(\mathrm{mm} \mathrm{d}^{-1}\right)=$ $-0.04 \log \mathrm{X}+0.67 \mathrm{~mm}$, when solved for $\log \mathrm{X}=0$ (i.e. when density $=1$ larva $\mathrm{m}^{-3}$ ), gives a potential growth rate of $0.67 \pm 0.15 \mathrm{~mm} \mathrm{~d}^{-1}$ with $95 \%$ confidence intervals, equivalent to instantaneous growth-in-length coefficients of $\mathrm{G}_{\mathrm{L}}=0.12 \pm 0.02 \mathrm{~d}^{-1}$. The highest growth rate that was observed in the enclosure experiments was $G_{L}=0.13 \mathrm{~d}^{-1}$ for an individual larva at the $50 \mathrm{l}^{-1}$ prey level.

The variability in $G_{L}$ of surviving larvae in the stocking density experiments also was high. Individual rates ranged from 0.06 to $0.11 \mathrm{~d}^{-1}$, with CVs about the means ranging from $3.9 \%$ at 10 eggs $\mathrm{m}^{-3}$ to $9.6 \%$ at $\sim 1300$ eggs $\mathrm{m}^{-3}$ (Table 3 ). Both the range in $\mathrm{G}_{\mathrm{L}}$ of survivors within stocking density treatments and the CV 


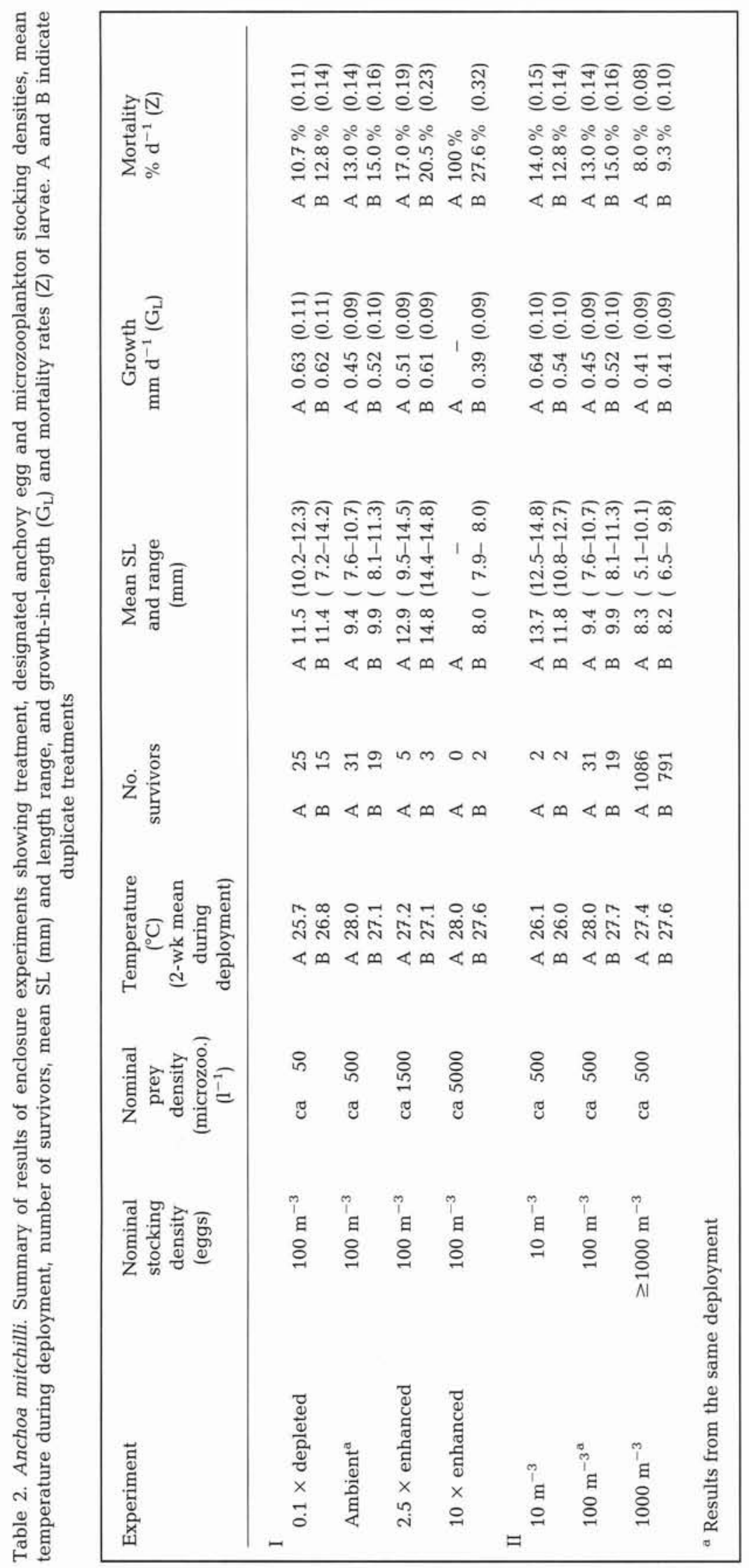


Table 3. Anchoa mitchilli. Treatment, number of survivors, values of instantaneous growth-in-length $\left(G_{L}\right)$ coefficients (mean, minimum, maximum, range of $G_{L}$ ) and coefficients of variation about the mean $G_{L}$ of individual larvae surviving to the end of the enclosure experiments. Also given is the estimated instantaneous growth-in-weight ( $\left.\hat{G}_{W}\right)$ coefficient, the ratio of growth-in-weight to mortality and estimates of relative production during the enclosure experiments

\begin{tabular}{|c|c|c|c|c|c|c|c|c|c|c|c|}
\hline \multirow[t]{2}{*}{ Experiment } & \multicolumn{2}{|c|}{ Survivors } & \multicolumn{4}{|c|}{ Values of $\mathrm{G}_{\mathrm{L}}\left(\mathrm{d}^{-1}\right)$} & \multirow{2}{*}{$\begin{array}{l}\text { CV } \\
(\%)\end{array}$} & \multirow{2}{*}{$\begin{array}{c}\hat{G}_{W} \\
\left(d^{-1}\right)\end{array}$} & \multirow[t]{2}{*}{$\hat{G}_{W}: Z$} & \multirow{2}{*}{$\frac{\hat{\mathrm{P}}}{\left(\mu \mathrm{g} \mathrm{m}^{-3}\right.} \underset{\left.\mathrm{d}^{-1}\right)}{ }$} & \multirow{2}{*}{$\begin{array}{c}\hat{\mathrm{P}}_{\mathrm{s}} \\
(\mu \mathrm{g} \mathrm{egg} \\
\left.\mathrm{m}^{-3} \mathrm{~d}^{-1}\right)\end{array}$} \\
\hline & No. & $\%$ & Mean & Min. & Max. & Range & & & & & \\
\hline \multicolumn{12}{|l|}{ I } \\
\hline $0.1 \times$ depleted & 40 & 10.1 & 0.11 & 0.08 & 0.13 & 0.05 & 9.7 & 0.24 & 1.95 & 999.33 & 14.48 \\
\hline Ambient $^{\mathrm{a}}$ & 50 & 7.8 & 0.10 & 0.08 & 0.11 & 0.03 & 7.0 & 0.20 & 1.34 & 776.45 & 7.76 \\
\hline $2.5 \times$ enhanced & 8 & 1.3 & 0.09 & 0.07 & 0.09 & 0.02 & 9.3 & 0.21 & 1.01 & 544.51 & 5.45 \\
\hline $10 \times$ enhanced & 2 & 0.3 & 0.09 & 0.09 & 0.09 & 0.01 & 0.3 & 0.19 & 0.59 & 428.48 & 4.28 \\
\hline \multicolumn{12}{|l|}{ II } \\
\hline $10 \mathrm{~m}^{-3}$ & 4 & 6.3 & 0.10 & 0.09 & 0.11 & 0.02 & 3.9 & 0.23 & 1.59 & 143.71 & 14.37 \\
\hline $100 \mathrm{~m}^{-3^{a}}$ & 50 & 7.8 & 0.10 & 0.08 & 0.11 & 0.03 & 7.0 & 0.20 & 1.34 & 776.45 & 7.76 \\
\hline$\geq 1000 \mathrm{~m}^{-3}$ & 1877 & 22.6 & 0.09 & 0.06 & 0.11 & 0.05 & 9.6 & 0.17 & 1.91 & 11271.59 & 8.68 \\
\hline
\end{tabular}

increased significantly as stocking density increased (regression analyses, $\mathrm{p}<0.02$ and $\mathrm{p}<0.03$, respectively), although standard morphologic comparisons of larvae condition did not vary significantly between stocking density treatments (ANCOVA, $\mathrm{p}>0.07$ ).

Instantaneous daily mortality rates of bay anchovy eggs and larvae decreased as egg stocking density increased (Table 2). Mortality rate was lowest at the highest initial egg stocking density $\left(8.5 \% \mathrm{~d}^{-1}\right)$ but averaged $13.5 \% \mathrm{~d}^{-1}$ in the other enclosures (ANOVA, $p<0.03$ ). There was no systematic change in the ratio of $\hat{G}_{\mathrm{W}} \mathrm{Z}$ in relation to stocking density or mean temperature. However, the estimate of standardized production (Table 3 ) was significantly higher at the lowest (10 eggs $\mathrm{m}^{-3}$ ) stocking density but similar in the 100 and $\geq 1000$ eggs $^{-3}$ enclosures (ANOVA, $\mathrm{p}<0.02$ ).

\section{DISCUSSION}

Physical and chemical properties of waters inside the enclosures appeared to be in equilibrium with ambient waters despite the relatively high degree of fouling which occurred by the end of the experiments. This suggests that the growth environment inside the enclosures was similar to that experienced by bay anchovy larvae in the Bay. These results concur with those of de Lafontaine \& Leggett (1987a) who reported that water properties inside similar low-porosity enclosures resembled the ambient water of the colder and less turbid coastal bay in which they ran their experiments.

Higher DO in our enclosures probably was caused by algal photosynthesis. As the experiments progressed, the enclosures became fouled by epiphytic algae, par- ticularly in the upper third of the cylinder. Although most of the fouling occurred on the outside of the enclosures, significant amounts occurred on the inside walls. Oxygen produced by photosynthesis on the inside walls during daylight probably accounted in part for the observed increase in DO.

Lower light levels inside the enclosures presumably did not affect larvae feeding. The mean light level inside at $5 \mathrm{~m}$ depth ( $>8 \mu \mathrm{E} \mathrm{m}^{-2}$ or $350 \mathrm{lux}$ ) was higher than the value of 0.1 to 1.0 lux necessary for many marine fish larvae to successfully feed (Blaxter 1968, 1969, 1986, Chesney 1989).

Rapid growth and low mortality at the lowest prey level indicated that 50 prey $1^{-1}$ was suitable for growth and survival of bay anchovy larvae in these enclosures. Moreover, the highest individual growth rate $\left(\mathrm{G}_{\mathrm{L}}=\right.$ $0.13 \mathrm{~d}^{-1}, 0.81 \mathrm{~mm} \mathrm{~d}^{-1}$ ) was obtained from a larva surviving to $16 \mathrm{dph}$ at 50 prey $\mathrm{l}^{-1}$ (actual mean density $=651^{-1}$, Table 1 ). This suggests that some larvae in the low prey level enclosures were growing near their maximum rate. In laboratory rearings of bay anchovy larvae, highest growth occurred when prey exceeded $1000 \mathrm{l}^{-1}$ and few larvae survived at prey levels as low as $501^{-1}$ (Saksena \& Houde 1972, Houde 1977, 1978). Houde $(1978,1987)$ suggested that approximately 100 prey $1^{-1}$ might be a critical food level for the preysensitive larvae of bay anchovy based on laboratory experiments. Growth and survival rates of northern anchovy Engraulis mordax larvae also were demonstrated to increase at prey concentrations above 1000 $1^{-1}$ (O'Connell \& Raymond 1970); similar results have been observed for other marine fish larvae (Laurence $1974,1975,1977,1978$, Saksena \& Houde 1972, Houde $1977,1978)$. However, in laboratory rearings of the Japanese anchovy Engraulis japonica, Fukuhara \& 
Takao (1988) indicated that larvae growth rate may not increase as prey density increased or other environmental conditions became more favorable, i.e. cumulative temperature, if minimal nutrient requirements are met.

The contrast between our enclosure results for bay anchovy and results of laboratory studies are similar to those observed for other species that have been cultured in large enclosures. Øiestad $(1982,1985)$ and Houde (1985) noted that lower prey levels generally were sufficient to culture marine fish larvae in large enclosures and suggested that some laboratory results that indicated high required prey levels might be in error. Food at relatively low mean densities in large volume enclosures, and perhaps in the sea, may be available to larvae because of vertical structure and patchiness of prey (Øiestad 1983a, 1985, Gamble 1985, de Lafontaine \& Leggett 1987a) that can develop. But, some enclosure studies have shown little correlation between vertical distribution patterns of zooplankton and larval fish (Gamble \& Houde 1984, Gamble 1985, de Lafontaine \& Leggett 1987a).

Growth rates in our enclosures were comparable to or higher than those reported for bay anchovy larvae based on field estimates in areas with similar temperatures or from laboratory rearings at similar prey levels. Fives et al. (1986) reported $0.25 \mathrm{~mm} \mathrm{~d}^{-1}$ in Newport River Estuary, North Carolina at 24 to $25^{\circ} \mathrm{C}$. Leak \& Houde (1987) estimated mean rates of 0.43 to $0.56 \mathrm{~mm} \mathrm{~d}^{-1}$ in Biscayne Bay, Florida when temperatures were 24.4 to $30.7^{\circ} \mathrm{C}$. In the laboratory, Saksena \& Houde (1972) reported mean growth rates of 0.48 to $0.54 \mathrm{~mm} \mathrm{~d}^{-1}$ that were directly related to prey concentrations in the range of 621 to $3323 \mathrm{l}^{-1}$ at 27.0 to $30.0^{\circ} \mathrm{C}$. Houde (1978) obtained rates of 0.32 to $0.63 \mathrm{~mm}$ $\mathrm{d}^{-1}$ at prey levels from 27 to $4731 \mathrm{l}^{-1}$ at $26 \pm 1{ }^{\circ} \mathrm{C}$ and Leak \& Houde (1987) obtained a laboratory rate of 0.56 $\mathrm{mm} \mathrm{d}^{-1}$ at 1600 prey $1^{-1}$ and $25^{\circ} \mathrm{C}$.

There was considerable variability in $G_{L}$ of surviving larvae in both the prey level and stocking density experiments (Table 3 ). The variability was highest at the lowest prey level and at the highest initial egg stocking density. For the prey level treatments, the range of $G_{L}$ (maximum to minimum) for individual surviving larvae increased as prey concentration decreased even though there was no systematic increase in the CV. This suggests that low prey density did affect growth of some individuals, despite the small changes observed in mean growth rate among prey level treatments. The length-frequency distribution of surviving larvae from the lowest prey level enclosures (Fig. 3A) indicates that many larvae were growing slower than the mean rate of $0.63 \mathrm{~mm} \mathrm{~d}^{-1}$. The lengthfrequency distribution of surviving larvae at ambient prey levels (Fig. 3B) is less dispersed and indicated a narrower range of $\mathrm{G}_{\mathrm{L}}$ and $\mathrm{CV}$. Houde (1977) also reported that the relative variability in the indices of bay anchovy larvae growth and survival decreased as prey level increased from 100 to $5000 \mathrm{l}^{-1}$ in laboratory rearings.

In the stocking density experiments, mean growth rate of surviving larvae systematically decreased as stocking density increased, while both the range of $G_{L}$ and CV increased. Consequently, at the highest stocking density, more slower growing larvae were able to survive to the end of the experiments (Fig. $3 \mathrm{C}$ ) than at lower stocking densities (Fig. 3B). The minimum growth rate of a larva surviving to $16 \mathrm{dph}$ in a $\sim 1300$ eggs $\mathrm{m}^{-3}$ enclosure was $0.20 \mathrm{~mm} \mathrm{~d}^{-1}, \mathrm{G}_{\mathrm{L}}=0.06 \mathrm{~d}^{-1}$. The results indicate a density-dependent effect on growth rate, possibly due to competition for food among individual larvae, even though prey levels were

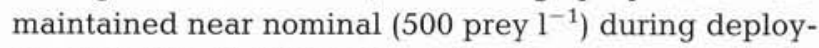
ment (Table 1). The initial ratio of prey organisms to bay anchovy larvae was 50:000:1 at the $10 \mathrm{~m}^{-3}$ egg stocking density but was only 500:1 in the $\sim 1300$ eggs $\mathrm{m}^{-3}$ enclosures. Although the ratio of prey numbers to larvae numbers at the highest egg stocking density improved to ca $1500: 1$ by the end of the experiment, the potential for competition among larvae may have remained high due to enhanced searching ability (Houde \& Schekter 1980) and increased prey capture success rates as the larvae grew (Chitty \& Houde 1981, Tucker 1989). As search rates and capture success rates increase, bay anchovy larvae increase their prey consumption rates (Houde \& Schekter 1980, Tucker 1989) raising the potential for competition when larvae are abundant.

Ratios of $\hat{G}_{\mathrm{W}}: \mathrm{Z}$ were above unity for all stocking density experiments (Table 3 ). However, mean standardized production, which integrates information on growth and mortality rates, was highest at the lowest stocking density $\left(14.37 \mu \mathrm{g} \mathrm{egg}^{-1} \mathrm{~d}^{-1}\right)$ but similar at 100 and $\geq 1000$ eggs $\mathrm{m}^{-3}$. The quite high productions in the highest stocking density enclosures were obtained because mortality rate declined. Estimated growth-inweight coefficients $\left(G_{W}=0.17 \mathrm{~d}^{-1}\right)$ in these enclosures were the lowest observed in all of our mesocosm experiments.

Other researches also have noted variability in the growth rate of marine fish larvae in large volume enclosures (Gamble et al. 1981, Øiestad \& Moksness 1981, Øiestad 1983b, Gamble 1985, Øiestad et al. 1985, Frank \& Leggett 1986). Øiestad et al. (1985) reported that daily specific growth-in-weight rate of cod Gadus morhua larvae ranged from 6 to $12 \% \mathrm{~d}^{-1}$ during their first $20 \mathrm{dph}$. Mean growth rate of larval capelin MaIlotus villosus in $400 \mathrm{~m}^{3}$ enclosures stocked with varying prey levels ranged from 0.13 to $0.25 \mathrm{~mm} \mathrm{~d}^{-1}$, giving CV's ranging from 12 to $41 \%$ (Frank \& Leggett 1986). 
Fig. 3. Anchoa mitchelli. Length-frequency distributions of bay anchovy larvae surviving to the end of enclosure experiments where: (A) eggs stocked at $100 \mathrm{~m}^{-3}$ and prey level $=50 \mathrm{1}^{-1}(0.1 \times$ depleted $) ;(\mathrm{B})$ eggs stocked at $100 \mathrm{~m}^{-3}$ and prey level $=500 \mathrm{l}^{-1}$ (ambient); and (C) eggs stocked at $\geq 1000 \mathrm{~m}^{-3}$ and prey level $=500 \mathrm{l}^{-1}$. Arrows indicate mean standard length (mm) of surviving larvae
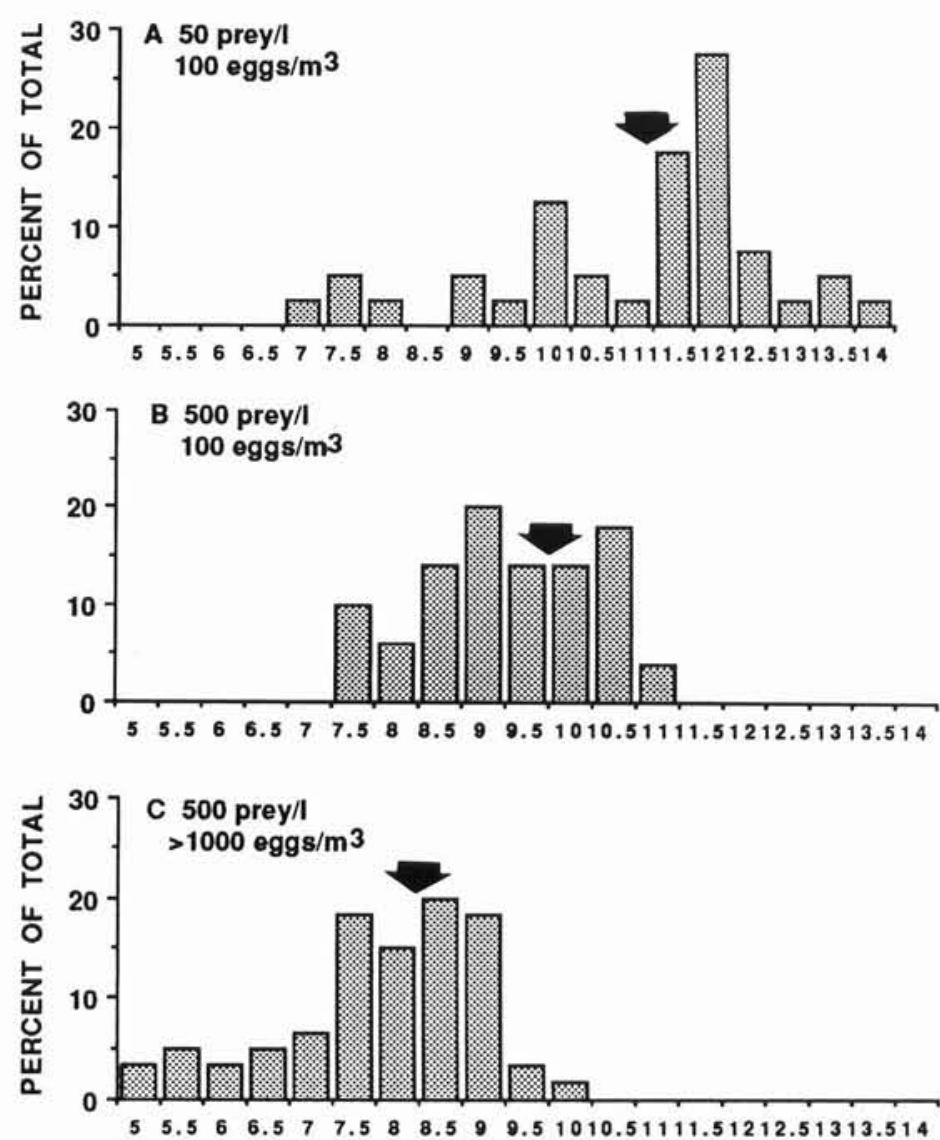

LENGTHCLASS
Growth rate of larval Atlantic herring Clupea harengus harengus in $300 \mathrm{~m}^{3}$ enclosures containing in situ plankton populations ranged from 0.137 to $0.407 \mathrm{~mm} \mathrm{~d}^{-1}$ (Gamble et al. 1985).

Daily mortality rates ( 10 to $15 \% \mathrm{~d}^{-1}$ ) of bay anchovy larvae in our enclosures with near ambient prey levels $\left(\leq 500 \mathrm{l}^{-1}\right)$, in the absence of large predators, were lower than field estimates of ca $30 \% \mathrm{~d}^{-1}$ in a Chesapeake Bay subestuary (Houde et al. unpubl.) and 22 to $39 \% \mathrm{~d}^{-1}$ in Biscayne Bay, Florida (Leak \& Houde 1987), but slightly higher than in laboratory rearings at similar prey levels (Saksena \& Houde 1972, Houde 1978, Houde \& Schekter 1978). The unexpected higher mortality rates of larvae at the higher prey levels may have been caused, in part, by injuries from bites by some of the organisms originally provided as prey. Cyclopoid copepod nauplii as well as small amphipods were stocked with the food; as some grew into adults, they may have become biting predators of fish larvae (Bailey \& Houde 1989).

Ratios of $\hat{G}_{W}: Z$ above unity suggest that larval populations in the enclosures were increasing in biomass in all but the highest prey level $\left(\sim 5000 \mathrm{l}^{-1}\right)$ experiment. Estimates of standardized production also were higher at lower $\left(\leq 15001^{-1}\right)$ prey levels (Table 3 ). The decrease in production with prey level and a low $\hat{G}_{\mathrm{W}}: \mathrm{Z}$ ratio $(0.59)$ at $\sim 5000$ prey $1^{-1}$ resulted mostly from increased mortality rate. Estimated mean $\hat{G}_{W}$ did not vary significantly among prey level treatments (ANOVA, $\mathrm{p}>0.05$ ).

Houde (1989) suggested that mortality rates often may exceed growth rates for teleost larvae in the sea, implying a loss of population biomass between the egg stage and metamorphosis in many species. The ratio of teleost mortality to growth rates (Z:G), based on coefficients in regression analyses of these rates corrected for temperature, is 1.31 (Houde 1989). If this relationship holds for bay anchovy in Chesapeake Bay, an average mortality of $\mathrm{Z}=0.29 \mathrm{~d}^{-1}$ would be expected, based on the estimated mean $\hat{G}_{\mathrm{W}}$ of $0.22 \mathrm{~d}^{-1}$ at prey levels of 50 to $1500 \mathrm{l}^{-1}$. The $\mathrm{Z}=0.29 \mathrm{~d}^{-1}$ rate is approximately twice the mean rate observed in our mesocosm experiments, indicating that some sources of mortality were absent from the enclosures.

The decrease in mortality rates of larvae at the highest egg/larvae stocking density also was surprising. Net and pump samples taken during the experiment showed that the zooplankton inside the enclosures with the highest egg stocking densities $\left(\sim 1300 \mathrm{~m}^{-3}\right)$ 
did not mature, apparently because the abundant anchovy larvae were consuming prey at a rapid rate. Microzooplankton prey occasionally was added to maintain nominal densities. Thus, there were more immature and fewer adult cyclopoid copepods and amphipods which could be biting predators. In contrast, it is probable that the higher mortaity rates at lower stocking densities were caused by significant numbers of biting predators. It should be noted that the unexpected changes in mortality rates occurred only in enclosures at the unusually high prey level $\left(5000 \mathrm{r}^{-1}\right)$ and initial egg stocking density $(\geq 1000$ $\left.1^{-1}\right)$. These levels are higher than ambient levels of prey or anchovy eggs in the Bay and were selected a priori to induce compensatory changes in larvae growth and possibly mortality rate. Mortality rates were similar $\left(\mathrm{Z}=0.14\right.$ to $\left.0.16 \mathrm{~d}^{-1}\right)$ in the 10 and 100 $\mathrm{m}^{-3}$ stocking density experiments.

In the Chesapeake Bay, prey levels or egg and larvae densities as high as $5000 \mathrm{l}^{-1}$ or $1000 \mathrm{~m}^{-3}$, respectively, would be unusual or ephemeral. Thus, the potential for dramatic changes in larvae mortality rates due to exceptional prey or larvae densities probably is lower than indicated by our experimental results. An important factor that differed in our experiment from conditions in the Bay was the exclusion of large predators. Large predators such as fish or gelatinous zooplankton would consume and thus reduce the numbers of potential biting predators and the numbers of abundant anchovy larvae. The latter effect could be especially important in regulating cohort-specific mortality rate, particularly if the predation rate on anchovy larvae were size-dependent (Beyer 1989).

In recent reviews of enclosure experiments, Øiestad et al. (1984) and Gamble (1985) noted that survival potential of most marine fish larvae, in the absence of predators, is high. Consequently, it was not surprising that the mortality rate ( 10 to $15 \% \mathrm{~d}^{-1}$ ) of bay anchovy larvae in our enclosure experiments was $\sim 50$ to $75 \%$ less than in field estimates from estuaries with predators present. In other mesocosm experiments, similar differences between mortality rates (excluding large predators) and field estimates have been reported (Laurence et al. 1979, Gamble et al. 1985, Øiestad 1985, Frank \& Leggett 1986). When predators are present in enclosures, mortality of fish larvae can be high (Øiestad 1985, Gamble \& Fuiman 1987, de Lafontaine \& Leggett 1988, Fuiman \& Gamble 1988). Conditions such as low prey and high larvae density acted to reduce the growth rate of some bay anchovy larvae in the enclosures. Because slow growth prolongs the larval stage, the cumulative predation mortality of slowgrowing bay anchovy larvae in Chesapeake Bay, in contrast to our enclosures, would increase even if daily mortality rate remained constant.
Acknowledgements. We thank Brian Moser, Bob Nyman, Ed Rutherford, Colleen Zastrow and Doreen Monteleone for assistance in the field and laboratory during these experiments. G. H. Jones, the U.S. Navy, and the Patuxent Naval Air Station, Solomons Annex, provided an ideal location and logistical support for this project. Funding was provided by National Science Foundation Grant OCE-8701304.

\section{LITERATURE CITED}

Bailey, K. M., Houde, E. D. (1989). Predation on early developmental stages of marine fishes and the recruitment problem. Adv, mar. Biol. 25: 1-83

Baird, D., Ulanowicz, R. E. (1990). An energy flow network for the Chesapeake Bay. Ecol. Monogr. 59: 329-364

Beyer, J. E. (1989). Recruitment stability and survival - simple size-specific theory with examples from the early life dynamics of marine fish. Dana 7: 45-147

Blaxter, J. H. S. (1968). Visual thresholds and spectral sensitivity of herring larvae. J. exp. Biol. 48: 39-53

Blaxter, J. H. S. (1969). Visual thresholds and spectral sensitivity of flatfish larvae. J. exp. Biol. 51: 221-230

Blaxter, J. H. S. (1986). Development of sense organs and behavior of teleost larvae with special reference to feeding and predator avoidance. Trans. Am. Fish. Soc. 115: 98-114

Chesney, E. J. Jr (1989). Estimating the food requirements of striped bass larvae Morone saxatilis: effects of light, turbidity and turbulence. Mar. Ecol. Prog. Ser. 53: 191-200

Chitty, N., Houde, E. D. (1981). Laboratory studies on interactions between two species of anchovy larvae. Int. Coun. Explor. Sea, C. M. 1981/L: 29: 1-7

Cushing, D. H. (1975). Marine ecology and fisheries. Cambridge Univ. Press, Cambridge

de Lafontaine, Y., Leggett, W. C. (1987a). Evaluation of in situ enclosures for larval fish studies. Can. J. Fish. Aquat. Sci. 44: $54-65$

de Lafontaine, Y., Leggett, W. C. (1987b). Effect of container size on estimates of mortality and predation rates in experiments with macrozooplankton and larval fish. Can. J. Fish. Aquat. Sci. 44: 1534-15543

de Lafontaine, Y., Leggett, W. C. (1988). Predation by jellyfish on larval fish: an experimental evaluation employing in situ enclosures. Can. J. Fish. Aquat. Sci. 45: 1173-1190

Fives, J. M., Warlen, S. M., Hoss, D. E. (1986). Ageing and growth of larval bay anchovy, Anchoa mitchilli, from the Newport River estuary, North Carolina. Estuaries 9: 362-367

Frank, K. T., Leggett, W. C. (1986). Effect of prey abundance and size on the growth and survival of larval fish: An experimental study employing large volume enclosures. Mar. Ecol. Prog. Ser. 34: 11-22

Fuiman, L. A., Gamble, J. C. (1988). Predation by Atlantic herring, sprat, and sandeels on herring larvae in large enclosures. Mar. Ecol. Prog. Ser. 44: 1-6

Fukuhara, O., Takao, K. (1988). Growth and larval behavior of Engraulis japonica in captivity. J. appl. Ichthyol. 4: 158-167

Gamble, J. C. (1985). More space for the sparsely distributed: an evaluation of the use of large enclosed experimental systems in fish larval research. Int. Coun. Explor. Sea, C.M. 1985/Mini-Symposium 2: 1-13

Gamble, J. C., Houde, E. D. (1984). Growth, mortality and feeding of cod (Gadus morhua L.) larvae in enclosed water columns and in laboratory tanks. In: Dahl, E., Danielssen, D. S., Moksness, E., Solemdal, P. (eds.). The propagation of cod, Gadus morhua L. Flødevigen rapportser 1: 123-143 
Gamble, J. C., Fuiman, L. A. (1987). Evaluation of in situ enclosures during a study of the importance of starvation to the vulnerability of herring larvae to a piscine predator. J. exp. mar. Biol. Ecol. 113: 91-103

Gamble, J. C., MacLachlan, P., Nicoll, N. T. Baxter, I. G. (1981). Growth and feeding in Atlantic herring larvae reared in large plastic enclosures, Rapp. P.-v. Réun. Cons. perm. int. Explor. Mer 178: 121-134

Gamble, J. C., MacLachlan, P., Seaton, D. D. (1985). Comparative growth and development of autumn and spring spawned herring larvae reared in large enclosed ecosystems. Mar. Ecol. Prog. Ser. 26: 19-33

Hildebrand, S. F., Schroeder, W. C. (1928). Fishes of the Chesapeake Bay. U.S. Bur. Fish., Bull. 43: 1-366

Houde, E. D. (1977). Food concentration and stocking density effects on survival and growth of laboratory-reared larvae of bay anchovy Anchoa mitchilli and lined sole Achirus lineatus. Mar. Biol. 43: 333-341

Houde, E. D. (1978). Critical food concentrations for larvae of three species of subtropical marine fishes. Bull. mar. Sci. 28: $395-411$

Houde, E. D. (1985). Mesocosms and recruitment mechanisms. Int. Coun. Explor. Sea, C. M. 1985/Mini-Symposium 4. 1-13 pp.

Houde, E. D. (1987). Fish early life dynamics and recruitment variability. Am. Fish. Soc. Symp. 2: 17-29

Houde, E. D. (1989). Comparative growth, mortality, and energetics of marine fish larvae: temperature and implied latitudinal effects. Fish. Bull. U.S. 87: 471-496

Houde, E. D., Schekter, R. C. (1978). Simulated food patches and survival of larval bay anchovy, Anchoa mitchilli, and sea bream, Archosargas rhomboidalis. Fish Bull. U.S. 76: 483-487

Houde, E. D., Schekter, R. C. (1980). Feeding by marine fish larvae: development and functional responses. Environ. Biol. Fish 5: 315-334

Hunter, J. R. (1981). Feeding ecology and predation of marine fish larvae. In: Lasker, R. (ed.) Marine fish larvae: morphology, ecology and relation to fisheries. Univ. Washington Press, Seattle, p. 33-77

Lasker, R. (1981). The role of a stable ocean in larval fish survival and subsequent recruitment. In: Lasker, R. (ed.) Marine fish larvae: morphology, ecology and relation to fisheries. Univ. Washington Press, Seattle, p. 80-87

Laurence, G. C. (1974). Growth and survival of haddock (Melanogrammus aeglefinus) larvae in relation to planktonic prey concentration. J. Fish. Res. Bd Can. 31: 1415-1419

Laurence, G. C. (1975). Laboratory growth and metabolism of the winter flounder Pseudopleuronectes americanus from hatching through metamorphosis at three temperatures. Mar. Biol. 32: 223-229

Laurence, G. C. (1977). A bioenergetic model for the analysis of feeding and survival potential of winter flounder, Pseudopleuronectes americanus, larvae during the period from hatching to metamorphosis. Fish. Bull. U.S. 75: $529-546$

Laurence, G. C. (1978). Comparative growth, respiration and delayed feeding abilities of larval cod (Gadus morhua) and haddock (Melanogrammus aeglefinus) as influenced by temperature during laboratory studies. Mar. Biol. 50: 1-7

This article was submitted to the editor
Laurence, G. C., Halavik, T. A., Burns, B. R., Smigielski, A. S. (1979). An environmental chamber for monitoring 'in situ' growth and survival of larval fishes. Trans. Am. Fish. Soc. 108: $197-203$

Leak, J. C., Houde, E. D. (1987). Cohort growth and survival of bay anchovy Anchoa mitchilli larvae in Biscayne Bay, Florida. Mar. Ecol. Prog. Ser. 37: 109-122

O'Connell, C. P., Raymond, L. P. (1970). The effect of food density on survival and growth of early post yolk-sac larvae in the northern anchovy (Engraulis mordax Girard) in the laboratory. J. exp. mar. Biol. Ecol. 5: 187-197

Øiestad, V. (1982). Application of enclosures to studies on the early life history of fishes. In: Grice, G. D., Reeve, M. R. (eds.). Marine mesocosms, biological and chemical research in experimental systems. Springer-Verlag, New York, p. 49-62

Øiestad, V. (1983a). Growth and survival of herring larvae and fry (Clupea harengus L.) exposed to different feeding regimes in experimental ecosystems: outdoor basin and plastic bags. Ph. D. thesis, Univ. of Bergen

Øiestad, V. (1983b). Predation of fish larvae as a regulatory force illustrated in enclosure experiments with large groups of larvae. NAFO SCR Doc. $83 / 1 \mathrm{x} / 73$, Serial No. N739: $1-14$

Øiestad, V. (1985). Predation on fish larvae as a regulatory force, illustrated in mesocosm studies with large groups of larvae. NAFO Sci. Coun. Studies 8: 25-32

Øiestad, V. (1988). Specific application of meso- and macrocosms for solving problems in fisheries research. Int. coun. explor. Sea. Early Life History Symp. Paper No 78: 1-19

Øiestad, V., Folkvord, A., Kvenseth, P. G. (1985). Growth patterns of Atlantic cod larvae (Gadus morhua L.) from first feeding to metamorphosis studied in a mesosocm. Int. Coun. Explor. Sea, C. M. 1985/Mini-Symposium/No 9: 1-15

Øiestad, V., Moksness, E. (1981). Study of growth and survival of herring larvae (Clupea harengus L.) using plastic bag and concrete basin enclosures. Rapp. P.-v. Réun. Cons. int. Explor. Mer 178: 144-149

Øiestad, V., Kvenseth, P. G., Moksness, E., Pedersen, T. (1984). Mesocosm studies on fish larvae from 1975 to 1984. Int. Coun. Explor. Sea, Working Group Meeting, Hirtshals, Nordsøcenteret, p. 1-10

Ricker, W. E. (1975). Computation and interpretation of biological statistics of fish populations. Bull. Fish. Res. Bd Can. 191: 1-382

Saksena, V. P., Houde, E. D. (1972). Effect of food level on the growth and survival of laboratory-reared larvae of bay anchovy (Anchoa mitchilli Valenciennes) and scaled sardine (Harengula pensacolae Goode and Bean). J. exp. mar. Biol. Ecol. 8: 249-258

Taggart, C. T., Leggett, W. C. (1987). Short-term mortality in post-emergent larval capelin Mallotus villosus. I. Analysis of multiple in situ estimates. Mar. Ecol. Prog. Ser. 41: 205-217

Theilacker, G. H. (1978). Effect of starvation on the histological and morphological characteristics of jack mackerel, Trachurus symmetricus, larvae. Fish. Bull. U.S. 76: 403-414

Tucker, J. W. (1989). Energy utilization in bay anchovy, Anchoa mitchilli, and black sea bass, Centropristis striata striata, eggs and larvae. Fish. Bull. U.S. 78: 279-293

Manuscript first received: February 7, 1990

Revised version accepted: August 30, 1990 